\title{
THE WOUNDS OF POST-SOCIALISM : A SYSTEMATIC REVIEW OF THE SOCIAL DETERMINANTS OF MORTALITY IN HUNGARY
}

\author{
Manuscript accepted for publication (not the final published version)
}

Journal of Contemporary Central and Eastern Europe, Published online: 17 Nov 2017

Gábor Scheiring, Darja Irdam \& Lawrence King

Department of Sociology, University of Cambridge, Cambridge, UK

CONTACT: Gábor Scheiring, gs385@cam.ac.uk

\begin{abstract}
Eastern Europe underwent one of the most dramatic economic and demographic changes in recent history with skyrocketing mortality rates in some countries during the 1990s. The case of Hungary among the post-socialist transition countries is puzzling for several reasons. Although the Hungarian transition has been often characterised as smooth and successful, a look at the human dimension of the transformation reveals large costs and a slow improvement. Based on the analysis of 29 articles we provide a systematic review of the empirical evidence about the social determinants of mortality in post-socialist Hungary establishing a hierarchy of causes. Socioeconomic position, mental health, social capital, alcohol consumption, stress, and social integration are the most important explanatory variables that received attention by the researchers. Although economic policies might have played a central role in the rise of mortality there is no empirical research on the political economy of health in Hungary. No critical analysis of post-socialism can be complete without assessing the human costs of economic transformation. Social scientists have much to learn from social epidemiologists who have designed robust methodologies and complex theoretical frameworks to analyse the political economic determinants of health.
\end{abstract}

Keywords: Social Determinants of Mortality, Political Economy of Health, Post-Socialism, Transition, Hungary 


\section{Introduction}

The post-socialist countries of Eastern Europe underwent one of the most dramatic economic and demographic upheavals in recent history. The life expectancy of the population living in former socialist countries was rapidly improving after the Second World War, but this positive trend reversed during the 1970s with a peak in mortality around the middle of the 1990s - a phenomenon that has been labelled as the post-communist mortality crisis. The case of Hungary among the post-socialist transition countries is puzzling for several reasons. Although the Hungarian transition has been often characterised as smooth and successful, a look at the human dimension of the transformation reveals large costs and a slow improvement. The economic recession that hit the country in the early 1990s not only caused a significant loss in income but a collapse of the labour market and a worsening of life chances. While other Central and Eastern European countries such as Poland, Czech Republic and Slovenia saw a steady improvement in life expectancy during the 1990s, mortality rates in Hungary have increased until 1993 (Kopp et al. 2007). Life expectancy at birth in Hungary in 2015 was 75.9 years, five years below that of Slovenia, three years below that of the Czech Republic and 1.5 years below Poland.

There is a growing literature addressing the issue of the post-socialist mortality crisis both in Hungary and beyond (Brainerd 1998; Rosefielde 2001; Bobak and Marmot 1996; Cornia and Paniccià 2000; Shkolnikov and Cornia 2000; Cockerham, Snead, and DeWaal 2002; Azarova et al. 2017; McKee 2001; McKee and Shkolnikov 2001; Stuckler, King, and McKee 2009; Haynes 2013). Yet as of today there is no systematic review of the scholarly work on the social determinants of mortality in Hungary. Russia's transition-related mortality crisis of staggering magnitude and proportions has understandably attracted a significant part of scholarly attention, leaving Hungary and other Eastern-European countries in similar situations less investigated. However, there might be important differences between the Visegrád-countries and Russia. Therefore we think it is fundamental to provide a systematic overview and assessment of the literature handling the social determinants of mortality in Hungary.

Understanding Hungary's puzzling mortality trajectory could shed light on the most important social and economic factors behind mortality and elucidate the reasons for the lack of effectiveness of demographic and public health policies and the slow improvement in human development in a transforming society. Why did Hungary fail to catch up to the West in terms of life expectancy and mortality? Are poor individual health choices to blame? Were individual decisions corrupted by a socialist legacy? Beyond the proximate causes of mortality, what is the role of social determinants in the dramatic population trends in post-socialist Hungary? How did rapid socioeconomic change influence mortality? Is the political economy of post-socialism implicated in the mortality crisis in Hungary? How has the literature coped with these intriguing questions? 
To find answers to these questions, this article presents the results of a systematic review of the English language within-country literature on the social determinants of mortality in Hungary, contextualised by an analysis of the long term trends in mortality and health behaviour. Our goals are to a) determine the gaps in the existing research; b) to evaluate and integrate the results of the literature by establishing a hierarchy of the most important social variables leading to changes in mortality patterns in Hungary; and c) to propose avenues for future research. By so doing we also hope to raise awareness on the developmental implications of mortality and draw closer the social scientific and epidemiological literatures on post-socialist change.

The systematic review method is used to identify, evaluate and integrate the findings of a large number of existing studies that address a pre-defined research question in a transparent, systematic and replicable way (Petticrew and Roberts 2006; Centre for Reviews and Dissemination 2008; Higgins and Green 2011). A systematic review is more than a narrative or traditional review that does not involve a systematic and replicable search strategy. A systematic review is thus less prone to bias than traditional reviews. We are reviewing the literature focusing on a broader topic in one country therefore the studies included encompass a heterogeneous set of dependent and independent variables. It is thus not appropriate to further quantify the review, such as in a meta-analysis. However, we go beyond a systematic review by comparing the performance of each set of variables calculating the ratio of significant to insignificant findings for each variable. We measured the performance of each set of variables by calculating the percentage of the studies that found the variable significant among those studies that included that particular variable. Ranking variables by their performance is an accepted methodology in economics, as evidenced by reviews focusing on financial crises and other instances of socio-economic shocks (Frankel and Saravelos 2012; Kaminsky, Lizondo, and Reinhart 1998). Adopting this approach to social determinants of mortality research allows us to systematically understand the best performing variables and integrate the findings of the existing literature.

Most of the published literature focuses on causes of mortality rates, analyses on changes are much less frequent. Yet, some causes of mortality are less and others are more likely to change over a short span of time. This review will put special emphasis on those determinants that a) might be implicated in the post-socialist mortality crisis, i.e. the sudden decline in life expectancy during the early 1990s; and b) that might explain longer term deviations from countries in the region. The article begins with portraying the mortality profile of Hungary using long term data collected from various international institutions as well as from the secondary literature. Second, the article provides methodological details on how this review was carried out, including search strategies and selection criteria. This review is based on the analysis of 29 articles as a result of a systematic search of scientific databases. A concise overview of the characteristics of the 29 studies is also presented. Third, the article provides a detailed review of the studies discussing the findings and causal mechanisms. The article analyses the performance of the variables by ranking them based on the number and percentage of the studies 
that found them significant. Finally, the discussion and the conclusion point out the broader implications of the results for the social scientific literature on the transition.

\section{Long term trends in mortality in Hungary}

\section{Sources of data}

Before presenting the results of the systematic literature review, we present long term data on mortality to portray the health profile of the country and thus contextualise the results of the review. For this purpose we relied on the following institutional databases: (1) data on the long term trends in life expectancy are collected from the Human Mortality Database created by the Department of Demography at the University of California, Berkeley, and at the Max Planck Institute for Demographic Research in Rostock; (2) data on cause specific mortality and individual lifestyle factors are collected from the WHO European Health for All database (HFA-DB); (3) data on real GDP growth are collected from the Penn World Tables constructed by Robert Summers and Alan Heston of the University of Pennsylvania, (4) data on inflation rates and total labour force participation are based on the World Development Indicators created by The World Bank, and (5) GINI indexes are calculated by taking the annual country averages of the multiple GINI indexes reported in the World Income Inequality Database created by the United Nations University World Institute for Development Economics Research (outlying GINI figures were eliminated to facilitate comparison). The online supplementary dataset contains the data used the plot the figures in the article in tabular format.

We use Austria and the average of the Visegrád countries excluding Hungary (Czech Republic [Czechoslovakia until 1992], Poland, Slovakia) as benchmarks. Austria is the nearest Western country with close historical ties to Hungary. Therefore comparing Hungary to Austria will help us to understand the long term dynamics and the development gap of Hungary (see Lackó 2011, as well). Comparing Hungary to the Visegrád average allows a short term comparison to the geographically and historically nearest block of post-socialist countries that is particularly useful to understand divergent trends during the transition period. Visegrád countries are the closest to Hungary in economic structure, social indicators, culture and politics. Hungary differs from other regions of post-socialist Europe more. The countries on the Balkans are geographically close but the war during the 1990s makes a comparison misleading. The former member states of the Soviet Union are different on a political and cultural level. The aim of using these benchmark categories is not to present a comparative analysis but to contextualise the Hungarian numbers. 


\section{Trends in longevity and health behaviour}

Just like in most part in Europe during the first part of the $20^{\text {th }}$ century, the life expectancy of Hungarians underwent a rapid improvement after the Second World War. Heavy investments into infrastructure and health care paid off as diseases of poverty like undernourishment and infections were significantly reduced (Orosz 1990a, , p. 848), though we have to bear in mind that Hungary still has a higher TBC mortality than Western European countries. Figure 1 portrays male life expectancy from 1959 on in Hungary, Austria and the Visegrád countries without Hungary. The post-war infrastructural developments were in fact so effectual that Hungary overtook Austria in terms of male life expectancy at birth for a brief period around 1966. In 1966 an average Hungarian man could expect to live almost a year longer compared to his Austrian counterpart. Yet, from the end of the 1960s the picture started to change. Whereas Western European countries experienced the epidemiological transition expressed through a reduction of chronic disease and cardio-vascular related mortality, the countries of Eastern Europe did not, thus a life expectancy gap opened up between East and the West. The improved western life expectancy is explained by the developments in the treatment and prevention of chronic diseases from the 1970s on mostly as a result of life-saving treatment and prevention based on new knowledge and technology. In contrast, in Eastern Europe there were no more gains to be made with massive infrastructural developments and the socialist welfare state proved to be less effectual in eliminating chronic and lifestyle diseases, especially cardiovascular mortality. Death rates continued to increase for a decade. The 1980s brought an improvement in life expectancy again but as the transition from a socialist to a market economy reached a threshold in 1988 mortality started to rise again. The 1985-1988 Gorbachev Anti-Alcohol Campaign was an important source of improvement in Russia (Chen, Wittgenstein, and McKeon 1996), however, its impact on mortality in Hungary is less important, as Central European countries were not subjected to the campaign (Bhattacharya, Gathmann, and Miller 2013). As the longevity of Austrians improved by a year between 1988 and 1994 the life expectancy of Hungarians at birth saw an equal decline.

Figure 1 here

Whereas the post-Soviet states as well as the Baltic countries underwent a major mortality crisis during the first half of the 1990s, the Visegrád countries managed the early transition years without any significant increase in mortality with the exception of Hungary. By 1993 the average Visegrád citizen could expect to live three years longer than the average Hungarian. The life expectancy of Hungarian men decreased by 1.6 years between 1989 and 1993. The difference to Austria grew even stronger over time, the average Austrian can expect to live almost six years longer than an average Hungarian in 2013. Working age men were affected by the increase in mortality the most, with the mortality rate of 40-69 aged men reaching higher levels than in the 1930s. In this group the death toll was higher by 11,395 men in 2005 than in 1960 in Hungary (Kopp et al. 2007, p. 326). This surge in 
Hungarian mortality rates was unique among the group of Central European post-socialist countries. Average life expectancy grew by more than a year in the Czech Republic, almost a year in Slovenia, and by half a year in Poland and by three months in Slovakia between 1989 and 1993. Today, the life expectancy of Hungarians is worse than it could be predicted based on the economic development of the country. Hungary's mortality rates were significantly higher than the average for the other Visegrád countries (Poland, Slovakia and Czech Republic) which is at odds with the high scores that the country has received for reform progress from international institutions. Hungary was for example ranked as the top performing transition country by the European Bank of Reconstruction and Development for seven consecutive years (Pogátsa 2009). Although other countries in Eastern Europe, such as Romania, Bulgaria, the Baltic countries and the majority of post-Soviet republics, suffered a similar or even more severe mortality crisis, Hungary`s divergence from her closest neighbours in the Visegrád-region with similar social, economic and cultural legacies and development trajectories during the transition is a puzzle.

Figure 2 here

Figure 2 portrays the trends in cause-specific death rates revealing some selected causes of mortality. Diseases of the circulatory system are by far the most important cause of death among Hungarians. The increase in cancer related mortality is also remarkable as well as the increase in alcohol related deaths during the turbulent years of the transition. As also pointed out by Leon et al. (1997) in relation to the increase in mortality in Russia, it is not likely that these changes are artefacts or coding errors. Infectious disease related mortality as well as infant mortality continued to decrease throughout these decades making it unlikely that the increase would be a result of biases in death certification. Genetic factors can also be ruled out as they cannot explain rapid temporal changes in mortality rates (Kopp, Csoboth, and Réthelyi 2004). It is also unlikely that the fluctuations in Hungarian mortality could be explained by the quality of the health care provision.

Although mortality amenable to health care is still higher in Hungary than in Western Europe (Nagy et al. 2012), the constant decrease in child mortality and infectious diseases that are most dependent on the state of the health care infrastructure shows that factors that are not directly related to the quality of the health care infrastructure might be behind the long term changes in mortality, especially the increase during the 1970s and the transition years in Hungary (Kopp et al. 2007, , p. 326). Finally, it is also very unlikely that environmental pollution could be behind the increase in mortality during the transition years. Environmental health actually improved from the end of the 1980s after the industrial collapse (Nell and Stewart 1994, , p. 17). As a result, environmental factors explain at most 3 per cent of post-communist mortality (Bobak and Feachem 1995). The unhealthy diet of Hungarians is a significant factor behind the higher rates of mortality in Hungary compared to Europe. However, the decrease in blood cholesterol levels of Hungarians between 1990 and 1995 shows that diets underwent 
a relative improvement and therefore could only give at best a partial explanation for the increasing mortality of the early transition years (Morava et al. 2000).

As the charts in Figure 2 show non-communicable or lifestyle diseases, i.e. avoidable mortality (cancer, circulatory diseases, and alcohol) played a crucial role in the increase of the mortality of Hungarians in the 1970s and during the early transition years. What explains the trend in lifestyle disease mortality? Alcohol has received the most attention from researchers of the post-socialist mortality crisis (Korotayev 2008; Rehm et al. 2007; Leon et al. 1997; McKee and Britton 1998), with researchers focusing on Hungary also pointing out its importance (Nagy et al. 2013). The relatively poor dietary patterns of Eastern Europeans compared to their Western European counterparts have also been pointed out as a potential mortality determinant (Stefler and Bobak 2015; Ginter 1995), however they are less likely to explain the rise in mortality during the 1990s (Morava et al. 2000). Diets, like many other social determinants are of changing in the long run, therefore new research has to re-assess its role in other time periods. Hazardous drinking patterns and poor health lifestyles have been associated with the socialist regime (Cockerham 1997). Some researchers link irresponsible individual behaviour with socialist ideology or the alleged culture of collectivism (Cockerham et al. 2006; Piko 2004). Although drinking and smoking are definitely important sources of the high mortality in Hungary, but path dependencies in health behaviour are not likely to be responsible for the change in mortality during the early 1990s. Alcohol consumption, is not always understood purely as an individual lifestyle factor even within the medically oriented social epidemiological literature, but often as a reaction to missing other consumption alternatives or a mediating factor between economic stress and mortality.

Figure 3 tracks the long term trends in key lifestyle factors in Hungary compared to Austria and the Visegrád countries. Among the four charts the first showing the increase in alcohol consumption is the only one that shows a significant diverging trend in Hungary and therefore can be considered as a significant factor behind the rise of mortality. The other lifestyle factors portrayed, such as fruit and vegetable consumption, smoking or fat intake are less likely to be significantly related to the increase in mortality. Although the alcohol consumption of Austrians was higher than that of Hungarians until 1976 the rapid increase in Hungarian alcohol consumption rates from 1974 till 1980 led to Hungarians consuming 1.5 times as much alcohol by 1982 as Austrians. We also have to take into account that steep changes in alcohol intake combined with other high risk behaviour (e.g. cholesterol rich food) might have an additive effect. The average alcohol consumption per capita in Hungary increased 2.2 times between 1951 and 1985 (Orosz 1990a, , p. 852). Drinking habits also changed during this period with the consumption of spirits increasing from 6 million litres in 1970 to 22 million litres in 1978 (Compton 1985).

Figure 3 here 
The 1980s show a slight decline both in alcohol consumption and in chronic liver diseases (not shown in the chart) followed by another steep increase between 1986-1990 for pure alcohol consumption and 1988-1994 for chronic liver diseases. At its peak in 1994, chronic liver disease and cirrhosis mortality were three times higher among Hungarians than among Austrians. Alcohol consumption on the whole was rapidly declining since 1990 followed by a rapid decline in chronic liver disease from 1994 onwards. The average alcohol consumption of Hungarians has been similar to Austrians or less since the second half of the 1990s. Although the level of alcohol consumed was historically lower in Hungary than in Austria (one should also note that high rates of homemade alcohol production not captured by official statistics might significantly alter the statistical picture of alcohol consumption) it could have played a significant role in the mortality increase during the 1970s and during the end of the 1980s. The steep increase in alcohol consumption in Hungary also stands out compared to the Visegrád countries. During the transition years the increase in mortality and alcohol related mortality was coupled with an overall decrease in alcohol consumption which suggests that drinking patterns and the quality of alcohol could be at least as important as the quantity of alcohol consumed.

\section{The economic context of mortality trends}

Immediate behavioural causes of mortality are embedded in a broader socioeconomic and power context. These background factors influence mortality in a variety of direct and indirect ways (WHO 2010). The heavy investment and intensive modernisation period following the Second World War resulted in a major restructuring of the Hungarian society. Tens of thousands of people left their villages and moved to newly built socialist industrial towns. As a result during the 1950s Hungary underwent a major equalisation in life chances also reflected in significant narrowing of mortality gaps across occupational classes (Kopp et al. 2007; Kopp and Réthelyi 2004). This trend toward more equality started to change during the 1960s (Orosz 1990a). Mortality rates of non-manual workers remained at the same level between 1940 and 1980 whereas agricultural and industrial workers saw a steep decline followed by a sharp increase from the 1970s onwards.

During the 1970s and the 1980s overwork and increasing stress led to the increase in alcohol consumption, both especially high among agricultural and unskilled workers (Molnár 1992). During the 1970s and 1980s increases in mortality in Hungary were highest among men who were widowed, had never married and, in particular, were divorced. On the other hand, as corroborated by many existing studies in different geographical settings, marriage appears to have a moderate protective effect on male mortality (Hajdu, McKee, and Bojan 1995). Mortality differentials by education, gender, region and occupational status grew, with the gender longevity gap reaching 8.3 years by 2001, twice the average gender difference in mortality in Western European countries. Hungary is affected with heavy regional health differentials as well (Uzzoli 2008; Uzzoli and Szilágyi 2009), with 
the gap between regions with the highest and lowest life expectancy reaching 8.1 years for men in 2008 (Gaal et al. 2011).

Figure 4 here

As it can be observed in Figure 4 Hungary's economic performance was constantly improving between 1970 and 1990, followed by a sharp decline in the early 1990s. The inflation rate was slowly increasing, staying below the Austrian and Visegrád inflation levels for the most of the 1970s. From the second half of the 1980s the inflation rate skyrocketed and stabilised only by the 2000s. With the gradual liberalisation of the socialist economy new opportunities emerged to supplement individual earnings and an increasing number of people took on second or third jobs in the shadow economy to offset the impact of inflation. To continue material improvement in the 1970s and to stop an outright fall in living standards during the 1980s as economic conditions worsened Hungarians engaged in an increasing amount of overwork. Time budget surveys conducted by sociologists during the 1980s show that Hungarians generally worked longer hours than citizens of other European countries (see Orosz 1990a, , p. 852).

The opportunities provided by the second economy during the 1970s resulted in a decrease in the GINI coefficient at the price of the ever-growing workload of the lower strata. After 1984 with the continuous liberalisation of the economy inequalities grew substantially until the middle of the 1990s followed by a gradual decline. A similar trend with a few years lag could be observed in the Visegrád countries. The most striking trend of the Hungarian economy compared to the benchmark countries is the steep decline in the active labour force that resulted in the lowest employment rate among European countries (EUROSTAT 2015). More than 80 percent of the working age population was engaged in economic activity before 1987. During the transition 1.5 million jobs were lost resulting in a total labour force participation rate below 50 per cent by 1996. The decline in the labour force participation rate in the post-socialist Visegrád region was much smaller suggesting that these countries could better cushion against the economic shock of the transitions.

This analysis of long term economic context of health behaviour suggests a correlation between the increasing mortality that started in the 1970s and high levels of social stress induced first by overwork in the 1970s and 1980s and then by growing inequality as well as the labour market shock during the early transition years in Hungary. To help disentangle the relationship between direct behavioural and indirect socioeconomic factors influencing life chances the next section provides a systematic analytical review of the social determinants of mortality in Hungary. The central question of the analytical review is if the existing literature on the social determinants of mortality in Hungary has offered any robust contextual explanations of mortality that take political economic factors into account. 


\section{Systematic literature review}

\section{Methods}

We collected English language articles from social science, public health and epidemiology journals that explicitly focus on the social dimension (gender, age, culture, socioeconomic status, as well as other macrosocial, and policy variables) of mortality in Hungary. Purely biological studies were excluded, with the exception of articles that focus on smoking and alcohol, as these have been shown to be directly related to social stress and mental health. We also excluded analyses of the health care system as it would require a different analytical strategy. ${ }^{1}$ We carried out systematic keyword-based searches of major medical and social science databases, including PubMed, Science Direct, Scopus, Sociological Abstracts and Web of Science as well as Google Scholar. The following search terms were used: Hungary mortality, Hungarian mortality, Hungary suicide, "social determinants of health", "social determinants of mortality", "social determinants of life expectancy", "welfare state" mortality, "mortality and transition". Hungarian language articles were excluded from the current review to ensure the international replicability of the analysis and the comparability of the results with studies in other contexts. $^{2}$

Several inclusion and exclusion criteria were applied to identify the appropriate studies through multiple rounds. Articles were first narrowed down based on their title and abstract to include studies that focus on Hungary and include at least one measure of social determinants. We extended this pool by looking for further articles that cite them in Scopus and included further missing articles. We also carried out additional search for similar articles in PubMed and Scopus using the built in "similar articles" functions. After the first round, we checked the bibliographies of all articles on the social determinants of mortality in Hungary and included further missing studies.

Within-country studies focusing on Hungary were included in the review (a focus on within country analyses), while multi-country studies were excluded. The focus on within country studies is warranted by the aim of the review to compare the methodology, study design and the theoretical

\footnotetext{
${ }^{1}$ Some of the studies included in the review also show that health care provision is not the most important explanatory factor of mortality rates. This is not to suggest that access to health care would not be of crucial importance, but the literature suggests that tackling social determinants of health like inequalities and labour market shocks could yield even higher health benefits.

${ }^{2}$ We only use articles published in English. We are aware that the addition of further Hungarian language articles would increase the richness of our review. However, our main concern is methodological. We are targeting an international audience that is interested in the social determinants of mortality in Eastern Europe and the relationship between economic change and health. We want to ensure easy access to the literature analysed which allows the falsifiability of our findings. Restricting the review to English language articles does not entail a judgement about the importance or superiority of English language publications. Additional Hungarian articles should be reviewed in the future targeting the Hungarian audience in specific.
} 
concepts of the articles. Including cross-country articles would increase the number of studies to the extent that a systematic review could not be carried out. We provide a separate review of the social determinants of the post-socialist mortality crisis in Eastern Europe using cross-country studies elsewhere in part compensating for excluding cross-country studies from the current analysis (Scheiring, Irdam, and King 2017). At the end of this article we briefly compare the literature on Hungary with the cross-country evidence on Eastern Europe.

Articles were sorted based on the dependent variable: analyses using some measure of mortality as a dependent variable were included in the literature review. Those articles that did not include at least one social determinant of mortality were excluded, except for the most important behavioural determinants of mortality (smoking and alcohol consumption) as well as studies on mental health. The reason for including smoking, alcohol and mental health related studies is that there is increasing evidence in the literature on the association between smoking, drinking, mental health and mortality. A relatively large number of studies are published in non-peer reviewed books or in the form of working papers, reports and manuscripts (Lackó 2015; Gaal et al. 2011; Szilágyi and Uzzoli 2014; Józan 1996; Elekes and Paksi 1999). We excluded papers that were not published in peer reviewed journals, with the only exception of the article by Kovács (2014) that appeared in a peer reviewed book-series published annually. After several rounds of iterative search a comprehensive list of 29 studies investigating the social determinants mortality in Hungary was compiled. The search process was closed on 31 January 2016.

Table 1 provides an overview of the studies and their major characteristics. Due to the large differences in methodology, study design and independent variables used it was not viable to carry out a quantitative meta-analysis of the social determinants of mortality in Hungary. However, the article provides a structured assessment of the importance and significance of different measures of social factors of mortality establishing a hierarchy among the causal determinants.

Table A1 here (or online appendix)

As Table A1 presents, there is a large heterogeneity in terms of methodology, variables used and time frame among the studies included in our review. The literature focusing on the crisis period in Hungary between 1989 and 1993 is scant, and most of the articles focus on a longer timeframe or offer a static explanation of differences in mortality.

\section{Social determinants of mortality}

Table 1 provides an overview of the different explanatory variables across the 29 studies we have reviewed with a count of the number of studies that found the particular group of variable significant 
or insignificant. The table only reports those studies that explicitly included a test of significance. The results of other studies that provide a description of trends without statistically measuring associations are reported in the review table in the Online Appendix. We also have to bear in mind that the small number of studies also means that there are several groups of variables that were only investigated in one or two articles. More research is needed to establish robust associations among different social factors and mortality outcomes.

Table 1 here (Table 2 if table A1 is inserted into the article and not presented as online appendix)

Table 1 shows that socioeconomic determinants of mortality were at the centre of the attention of the literature in question. Eleven studies found a measure of socioeconomic status significant with only one study (Kopp, Csoboth, and Réthelyi 2004) reporting no significant association. However, Kopp, Csoboth, and Réthelyi (2004) relied on cross sectional county level data that might hide a large part of the individual level variation in socioeconomic status. Studies that found a significant relationship between socioeconomic status and mortality report a strong effect in particular for personal income and even more so for education. Kopp et al. (2007) report that the odds ratio of death for men with low levels of education compared to men with education higher than secondary was 2.39 , adjusted for age. Skrabski, Kopp, and Kawachi (2004) found that education alone explained two thirds of the variation in middle aged male mortality at the level of sub-regions in a cross sectional linear regression (adjusted $\mathrm{r}^{2}=0.618$ ). Cross-national comparative studies also report that mortality differentials for males by education in Hungary are among the highest in Europe (Mackenbach et al. 1999; Leinsalu et al. 2009). Other measures of socioeconomic status, such as the lack of car in the family or blue collar worker status were also found to significantly increase the hazard of dying by around two times (Kopp et al. 2011). Generally, socioeconomic status variables are the most important predictors of mortality differences for all causes of death except for suicide where mental health and social capital variables play a leading role (Almasi et al. 2009).

As Table 1 portrays, mental health was found significant in six studies, a larger number than in crosscountry empirical work on Eastern Europe (Scheiring, Irdam, and King 2017). The Hungarostudy health survey series $(1988,1995,2002$, 2005, and 2013) led by Maria Kopp stands out for its depth and coverage among health related research projects in Hungary. Kopp and her research team recognised the role of mental health, depression, hopelessness, low self-efficacy and anxiety in mortality in Hungary and included relevant questions in their surveys from 1988 on. Using cross sectional linear regression at the level of counties Kopp, Csoboth, and Réthelyi (2004) found that variations in average GDP levels, depressive symptom severity and income inequality together explained 78.6 per cent of the variance in mortality among men, but women seem to be protected against the mortality increasing effect of depression. Comparing the 1988 and 1995 samples Kopp, Csoboth and Réthely found that depression score increased and control at work decreased substantially 
between 1988 and 1995 in parallel with an increase in alcohol consumption. Men appear to be significantly more vulnerable to status loss then women. Using data from a 2006 follow up study of the 2002 Hungarostudy survey Kopp et al. (2007) confirmed again that severe depression and anxiety were significant predictors of mortality among Hungarians. They report that the odds ratio of death for men reporting severe depression was 3.68 compared to those living without depression adjusted for age. However, depression was not significant among women. Kopp et al. conclude that the negative health consequences of low education among men works through depression and hopelessness induced by chronic stress as a result of work related factors.

Social capital appears to be a crucial mediating factor for Hungarians, with five out of five studies including a measure of social capital reporting a significant association with mortality. Using county level cross-sectional regressions based on the data from the 1995 Hungarostudy Skrabski, Kopp, and Kawachi (2003) found that all of the social capital variables were significantly associated with middle age mortality with general mistrust to society showing the strongest association, although county level GDP, unemployment and education were all more strongly correlated with mortality. These results were confirmed with later data using sub-regional level ecological regressions: Skrabski, Kopp, and Kawachi (2004) found that social capital, collective efficacy, as well as religious involvement were each significantly associated with middle age mortality. Using data from the 2002 Hungarostudy survey Kopp et al. (2007) confirmed that low social support from co-workers (age adjusted odds ratio $=2.03$ ) and low social support from spouses (age adjusted odds ratio $=4.03$ ) were significant predictors of male mortality but not of female mortality. Using a follow up study of the same survey Kopp et al. (2011) again found that both self-efficacy and social support were significantly lower among the deceased than among the surviving group of the sample.

The traditional behavioural risk factor of smoking was found significant in 6 studies out of the 29 and insignificant in one study. Using Pearson correlation Skrabski, Kopp, and Kawachi (2003) found no significant association between smoking and mortality in middle aged men at the level of counties. However, in a linear regression setting smoking became significant for both men and women. In a follow up study with sub-regional data from 2002 and 2006 Kopp et al. (2007) found no significant relationship between smoking and mortality in age adjusted models. The other traditional risk factor, alcohol consumption was significant in 5 studies and insignificant in 2. Using a time series regression model with national level aggregate data Lackó (2011) found a strong association between smoking and alcohol consumption and mortality. The author also points out that smoking in Hungary has been decreasing since the mid of the 1980s so it is less likely that is was implicated in the increase in mortality during the early transition years. Some researchers elevate the behavioural factors to the level of ultimate cause. For example, based on a review of long term trends, Józan (2002) argues that the increase in mortality between 1970 and 2000 in Hungary is solely a result of alcoholism and smoking. Józan questions the importance of stress and other socioeconomic background factors in 
explaining mortality change and argues that hazardous individual behaviour is a result of the socialist culture that supposedly encourages a patriarchal relationship with the state, where citizens rely on public provision of goods and services and are not used to being in charge of their own needs.

Stress has often been pointed out as an important mediating factor between adverse social change and detrimental health behaviour (Brainerd and Cutler 2005). Using inflation as a proxy for overwork (based on other empirical analyses that showed that Hungarians reacted to an increase in prices with more time spent on working) Lackó (2011) showed that stress induced by overwork has been an important background variable for mortality change. Lackó concludes that alcohol and tobacco was used to alleviate the stress induced by overwork as a response to decreasing real incomes. The 2006 follow up study by Kopp et al. (2007) reports extensive significant links between various measures of stress and mortality. The odds ratio of death among men experiencing work insecurity was 3.6 compared to the control group adjusted for age. Low work control and low employment status were also significantly related to mortality. Confirming Marmot's (2004) theory of the status syndrome Kopp et al. (2007) conclude that it is not the difficult social situation in itself, but the subjective experience of relative disadvantage and chronic stress is the most important risk factor. Measuring the relationship between hopelessness, anomie and mortality Kopp et al. (2007) also point out that a sense of meaning of life can help to counterbalance negative economic experiences.

Based on cross-sectional linear regression at the level of sub-regions Kopp et al. (2006) found that weekend work hours and social support at work together explain 14.7 per cent of middle aged male cardiovascular mortality. The role of work related stress was much less important in explaining mortality variations among women. This gender difference might be explained by the different coping strategies across genders with men more likely to engage in hazardous behaviour to alleviate stress. Comparing data from the 1988 and 1995 Hungarostudy survey using self-rated health as a dependent variable Kopp, Skrabski, and Szedmák (2000) point out that during the transition years there was a significant decrease in perceived control in work and in perceived social support from co-workers and friends, especially in the lowest socioeconomic groups, which also underpins the unified chronic stress theory approach to explaining the mortality increase during the transition. Kopp, Skrabski, and Szedmák (2000) found that depressive symptom severity mediates between relative socioeconomic deprivation and higher self-rated morbidity rates, especially among men. Low control at work, low perceived social support and emotional coping strategies are also strongly correlated with depressive symptoms, thus the researchers conclude that social deprivation, increased work or unemployment related stress, lack of active and positive coping strategies among the lower social classes and depressive symptomatology represent the vicious circle that explains the decreasing health of Hungarians during the transition years. Non-quantitative studies on the long term trends in mortality also underpin the centrality of overwork and stress on mortality (Molnár 1992). 
The importance of meaning of life and participation in political or religious activities, i.e. social integration has been established by several empirical papers included in our review. As can be seen in Table 2 four studies found a measure of social integration to be significantly associated with mortality. In a recent paper using a spatial autoregressive model Balint et al. (2014) found significant association between mortality, the lack of political involvement and the lack of religious involvement. Skrabski, Kopp, and Kawachi (2004) found significant associations between mortality and the lack of religious involvement, social mistrust and low collective efficacy using ecological level linear regressions. Kopp et al. (2007) found that the odds ratio of early mortality among men who reported no meaning in life was 2.62 adjusted for age. Hopelessness was strongly associated with female mortality. Conversely, people with higher levels of hope and increased meaning in life were protected against mortality. Thus both ecological and individual level measures of social integration seem to be significant protective factors against mortality. These ecological and individual level measures of social integration are in strong correlation with social capital, stress and mental health problems. As Kopp, Skrabski, and Szedmák (2000) and Skrabski, Kopp, and Kawachi (2004) pointed out positive coping strategies, individual signs of social integration and social capital, friends' support, civil society organisations and colleagues can be important mediating and protective factors between social change and health outcomes.

Unemployment was found to be a significant predictor of mortality in three studies (Skrabski, Kopp, and Kawachi 2003; Kopp et al. 2006; Lackó 2011), and insignificant in one study (Balint et al. 2014). Studies that did not include a significance test but provide a long-term review of trends also point out the strong association between ecological level unemployment and mortality (Uzzoli 2008; Uzzoli and Szilágyi 2009). Ecological level unemployment might be strongly correlated with income inequalities that was also found to be significantly associated with mortality (Kopp, Csoboth, and Réthelyi 2004) similarly to aggregate indicators of economic performance (Lackó 2011; Skrabski, Kopp, and Kawachi 2003). Balint et al. (2014) did not find a significant association between unemployment and suicide, whereas Döme et al. (2011) reported the lack of significant association between economic performance and suicide. This divergence from other studies can be both explained by the ecological level study design of Bálint et al. and Döme et al., or by the fact that suicide is more strongly correlated with mental health than with socioeconomic factors, as also confirmed by Rihmer et al. (2013).

It is worth mentioning that the two studies that measured the impact of medical services on mortality found no significant correlation (Balint et al. 2014; Lackó 2011). One of the studies uses suicide as the outcome variable, the other uses national level aggregate data on the number of doctors as a proxy for the quality of health infrastructure - these methodological decisions might explain the lack of significant impact. However, the ambiguity of the role of medical services in alleviating mortality in economically developed societies is also reflected in the cross-country empirical literature (Scheiring, 
Irdam, and King 2017). As infant mortality and infectious diseases are successfully combatted through infrastructural developments, the role of broader social factors increases in explaining mortality. This is in line with the finding of Stuckler, Basu, and McKee (2010), who reported that general welfare spending or austerity are more important predictors of mortality than levels of health care spending.

\section{Discussion: the Hungarian literature in the post-socialist context}

Hungarian mortality diverged from the other Visegrád-countries during the early transition years. Men lost 1.6 years in life expectancy between 1989 and 1993 in Hungary. Yet, this review of the literature on the social determinants of mortality in Hungary has shown that we still know very little about the contextual background factors of this major mortality crisis. Based on a systematic review 29 withincountry studies on the social determinants of mortality in Hungary this paper has found that the literature put most emphasis on 1) socioeconomic status; 2) mental health; 3) social capital; 4) alcohol; 5) stress; and 6) social integration as social determinants of mortality. Medical services seem to have been less influential in affecting mortality outcomes. Researchers analysing Hungary put more emphasis on mental health and social capital compared to the cross-country literature on Eastern Europe (Scheiring, Irdam, and King 2017). Measures of economic performance have been found significant in a large number of studies on post-socialist Eastern Europe similar to Hungary (Arinaminpathy and Dye 2010; Brainerd and Cutler 2005). Unemployment and labour market turnover have also been established as important divers of social stress, increased alcohol consumption and cardiovascular mortality (Walberg et al. 1998; Cornia and Paniccià 1996). Similar to Hungary, several studies have found an association between perceived control and mortality in cross-country studies (Marmot and Bobak 2000).

There is evidence in the literature that overwork during the 1970s and 1980s, drastic labour market upheaval during the 1990s were important background factors directly associated with mortality mostly through hazardous health behaviour. The experience of relatively poor socioeconomic position, status loss and hierarchy disruption during social change leads to chronic stress, depression, hazardous behaviours and increased mortality. This effect can be offset by better individual coping strategies, higher social cohesion and higher levels of social capital as several studies included in this review have also shown. However, the distal economic determinants remained underexplored in the literature on Hungary. Despite the theoretical and empirical relevance of economic policies and macroeconomic cycles these factors have not received enough attention in the context of Hungary. There is no quantitative research on the nature of transition, on the health impact of social and economic policies in the context of Hungary. There are only a very few studies on Hungary that explicitly deal with the mortality crisis between 1989 and 1993, the majority of the analyses review longer trends or offer static explanations of mortality differences. 
In contract to research on Hungary, cross-country studies have found the speed of privatisation, the change in the private sector share in employment and shock therapy type reforms in Russia to be significant predictors of mortality (Brainerd 1998; Stuckler, King, and McKee 2009; Minagawa 2013). However, some researchers questioned the robustness of the association between shock therapy and mortality arguing that the result was prone to ecological fallacy (Gentile 2012; Earle and Gehlbach 2010). A recently published article has shown that the association between mass privatisation and mortality was real, confirming the detrimental health effect of rapid privatisation using multilevel individual, company and settlement data (Azarova et al. 2017).

There are also important studies on the effect of liberalisation on mortality that show that in the short run liberalisation and democratisation might contribute to the increase in mortality that can be offset by its long term beneficial impact (Mackenbach, Hu, and Looman 2013). Cross country research has also showed that social welfare spending is associated with mortality, reporting a seven-times greater reduction in mortality due to welfare spending compared to GDP (Stuckler, Basu, and McKee 2010). In relation to economic policies participating in an IMF program was also showed to be associated with increased tuberculosis incidence, prevalence, and mortality rates (Stuckler, King, and Basu 2008) also in post-socialist countries.

We have also found that some articles analysing mortality in Hungary overemphasise individual lifestyle and individual health behaviour, elevating these factors to the status of the ultimate cause. These behaviourist researchers in essence argue that the survival of the socialist culture explains drinking, unhealthy eating and lack of health consciousness which in turn is responsible for Hungary's mortality crisis (Cockerham, Snead, and DeWaal 2002; Piko 2004). Józan (2002: 437) explicitly questioned the importance of stress and other socioeconomic background factors and proposed that irresponsible health behaviour (alcohol and smoking) explains mortality between 1970 and 1999 "almost completely", also adding, the "performance culture of capitalism" should slowly erode irresponsible health behaviour during the transition. Józan is not the only to overemphasise individual responsibility and downplay social structure as a determinant of health. This behaviourist approach to health is often adopted in social and economic policy discourses in Western European countries also, as it is compatible with the individualism of neoclassical economics thus creating a "lifestyle drift" in health policy (Smith 2013; Katikireddi et al. 2013; Mackenzie et al. 2016). Liberal economists also adopted the behaviourist view regarding health and suggested that by applying the policies of "shock therapy" or "the Washington consensus" and rapidly transforming enterprises former socialist countries can achieve rapid improvements in health (Lipton and Sachs 1992).

In contrast to the behaviourist approach, the rising political economy of health paradigm put emphasis on how broader economic processes influence health. There is accumulating evidence of the ways in which consequences of sudden economic transformations such as increasing precariousness of 
employment (Barlow et al. 2015), work (Waters 2014) and housing (Clair et al. 2016) impact adversely on health. Neoliberal policies have been empirically shown to increase health problems and mortality (Coburn 2000; De Vogli 2011), including the detrimental health effect of rapid privatisation (Azarova et al. 2017), structural adjustment (Kentikelenis 2017), or austerity (Karanikolos et al. 2013). Existing quantitative public health research has also demonstrated that deindustrialisation is associated among others with decreases in health insurance (Renner and Navarro 1989), reduced physical activity (Rind, Jones, and Southall 2014), increased mortality (Walsh, Taulbut, and Hanlon 2009), increased susceptibility to drug use (McLean 2016) as well as suicide (Kubrin, Wadsworth, and DiPietro 2006). However, these political economic factors have remained neglected as of today in the literature on mortality in Hungary.

\section{Conclusion}

The post-socialist mortality crisis represents the largest demographic catastrophe seen outside China since the Second World War (Eberstadt 2010). The magnitude of this human crisis stands in contrast to our limited understanding of the complexities how post-socialist global economic transformations influenced trends in mortality. Social scientists have much to learn from social epidemiologists who have designed robust methodologies and complex theoretical frameworks for analysing the political economic determinants of health. As it has been noted before, social scientists and area specialists should focus more on the mortality crisis in Hungary (Haynes 2013). No critical analysis of postsocialism can be complete without assessing the human costs of economic transformation. Viewed through the lens of mortality the transformation of socialist countries reveals immense human costs. If development includes a modicum of creative destruction we find that there was very little creative in the rising human suffering of the 1990s. Although the foundations of a critical political economy approach to mortality exists in the literature on Hungary in the form of analyses on the health impact of social stress, loss of control, hopelessness and unemployment, much remains to be done to understand how the political economy was implicated in the post-socialist mortality crisis.

Although the link has been rarely made, the social science literature on the post-socialist transformation has pointed out several features of the development trajectory of these countries that are relevant for explaining trends in longevity. First, the question of the speed of reforms has been thoroughly discussed from the perspective of economic and political theory (Stiglitz 1999; Stark and Bruszt 1998; Boycko et al. 1993; Murrell 1992). Research outside of the context of Hungary has also shown that shock-therapy type reforms have detrimental consequences (Azarova et al. 2017; Irdam, Scheiring, and King 2015). Hungary has adopted a mixture of gradualism and shock-therapy, future research should analyse the potential positive and negative implications of this policy mix, paying special attention to the combination of rapid liberalisation and prolonged state ownership of companies. Second, the literature on post-socialism has also analysed the social implications for 
international economic integration, such as the extensive deindustrialisation, the dramatic shock to people`s everyday lifestyles and the accumulation of experiences of rising uncertainties, increasing inequalities as well as the informalisation and re-feudalisation of social arrangements (Burawoy and Verdery 1999; Böröcz 1999; Kalb 2015). Even critical analysts of the semi-peripheral dependent development model followed by Hungary often characterised the country as successful compared to other Eastern European countries (King and Váradi 2002; Bohle and Greskovits 2007). Future research should analyse the health and mortality implications of this particular development model. Finally, the question of democratic consolidation has also been thoroughly analysed in the postsocialist region (Bunce 2006; Plasser, Ulram, and Waldrauch 1998). However, the social requisites of democracy received less attention which could in part explain why the illiberal turn of Hungarian politics took the majority of analysts by surprise. Future research could utilise the potential of mortality as an indicator of development which could serve as an important addition to assessing the success or failure of democratic consolidation in Hungary and beyond.

More than half of the world's population today lives in emerging or transition economies throughout the world undergoing major economic and political reforms. An improved understanding of the social determinants and the political economy of mortality in Hungary therefore bears relevance to other emerging countries representing a significant part of the world population. The importance of health and mortality goes beyond the most obvious direct impact on life chances. As Amartya Sen (1998) has argued, mortality can also be used as a robust indicator of economic development. In a time when an increasing number of countries undergo democratic backsliding it is also important that it has been shown that the legitimacy of political and economic institutions depends on their social performance (Lipset 1994). Thus, health and mortality might serve as a direct measure of the political and economic success of transition policies. Understanding the social determinants of mortality could not only lead to better evidence-based health policies, better and more equal life chances but through distributing the fruits of social transformation more evenly it could also improve the prospects of socially and democratically sustainable economic transformation.

\section{Acknowledgements}

The authors acknowledge the financial support of The European Research Council (ERC), grant number 269036. The funding body had no role in study design, data collection, data analysis, and reporting of this study.

The authors declare no conflicts of interest. 
The Wounds of Post-Socialism

\section{Figures and Tables}

Figure 1. Male life expectancy at birth in Hungary, Austria and the Visegrád countries

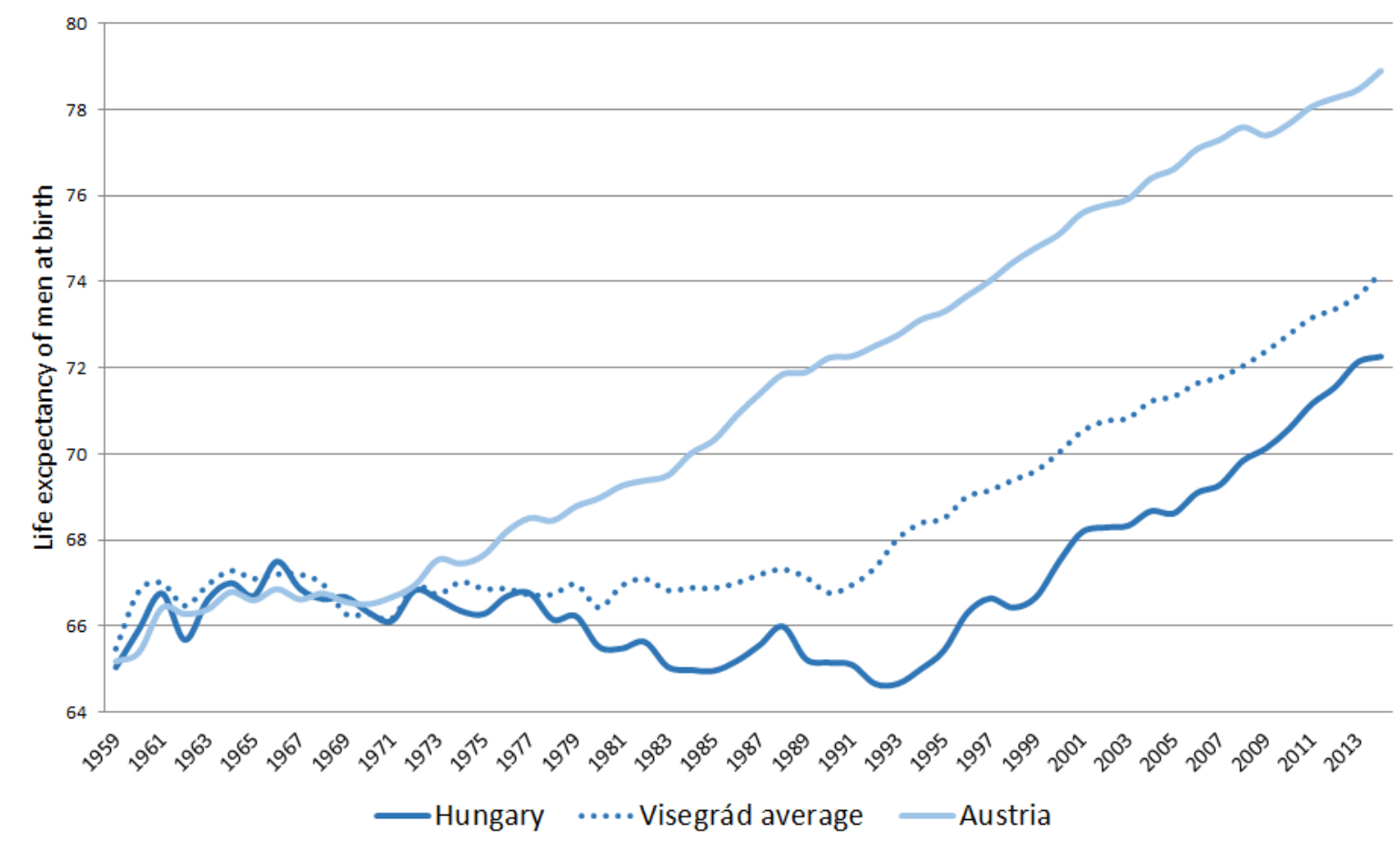

Source: Human Mortality Database 
Figure 2. Long Term Trends in Cause-Specific Mortality in Hungary, Austria and the Visegrád countries
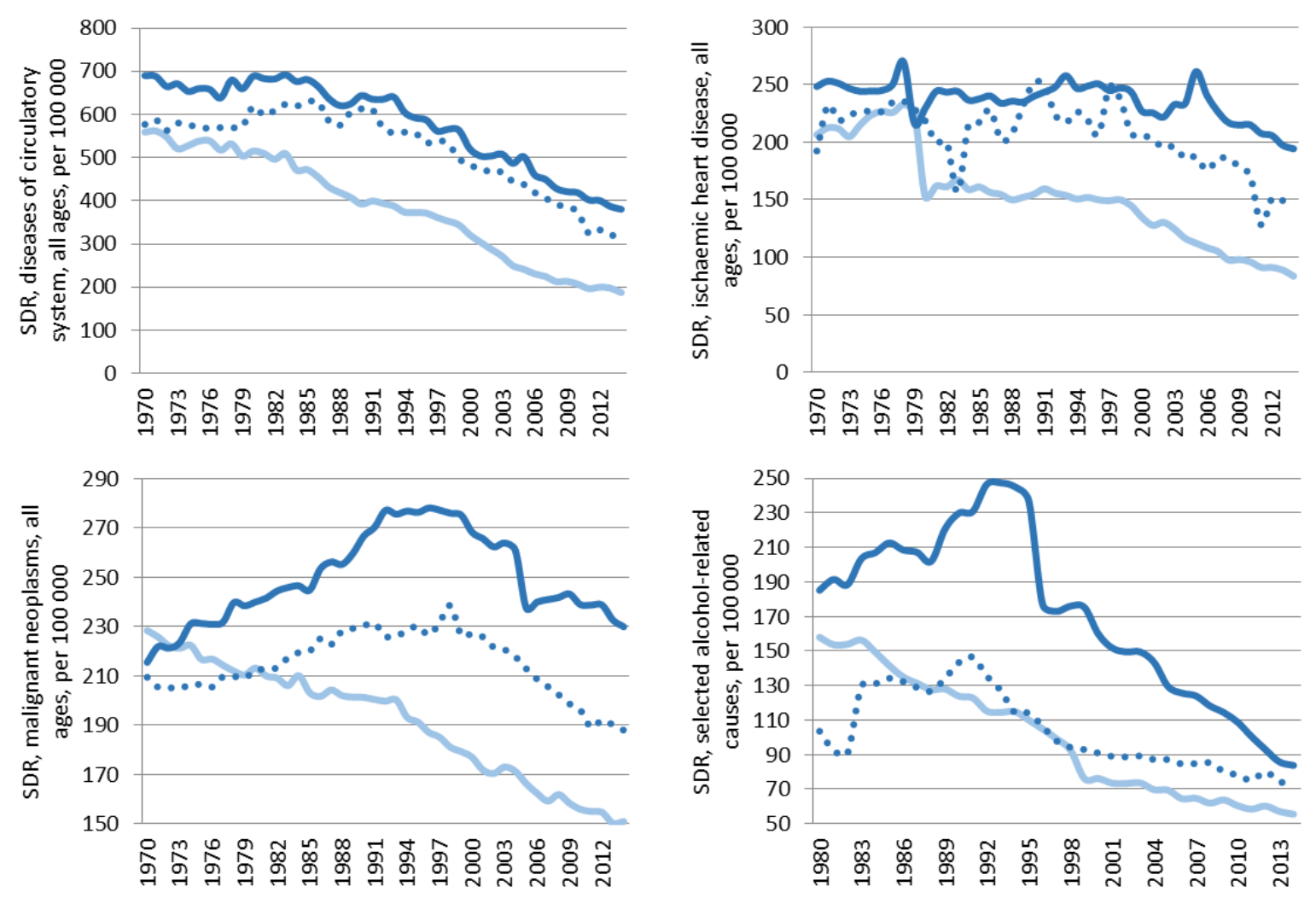

Hungary $\quad . .$. Visegrád average

Austria

Source of data: WHO HFA-DB; 
Figure 3. Trends in life style factors in Hungary, Austria and the Visegrád countries
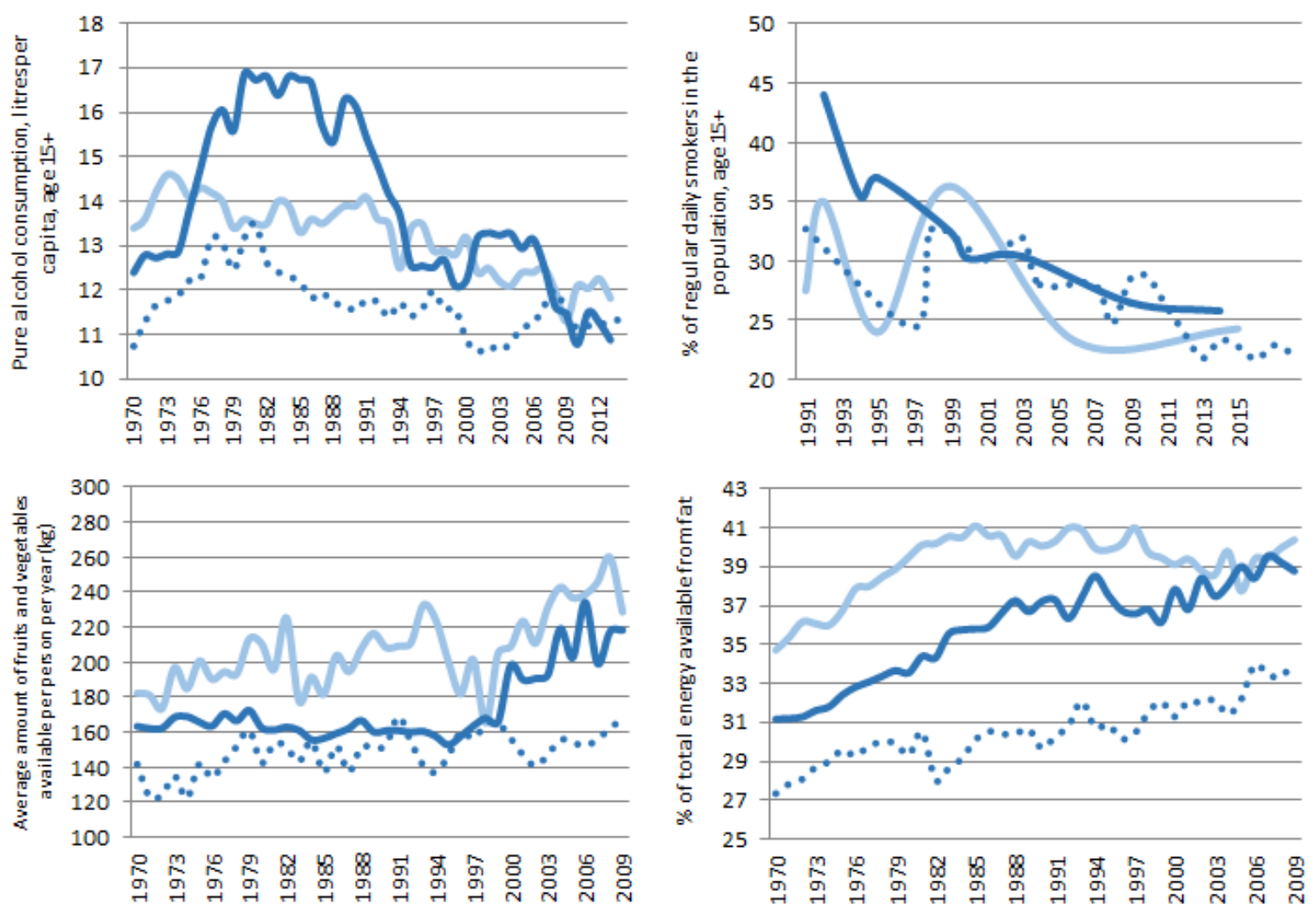

Hungary $\quad . .$. Visegrád average

Austria

Source of data: WHO HFA-DB; 
The Wounds of Post-Socialism

Figure 4. Social and economic trends in Hungary, Austria and the Visegrád countries
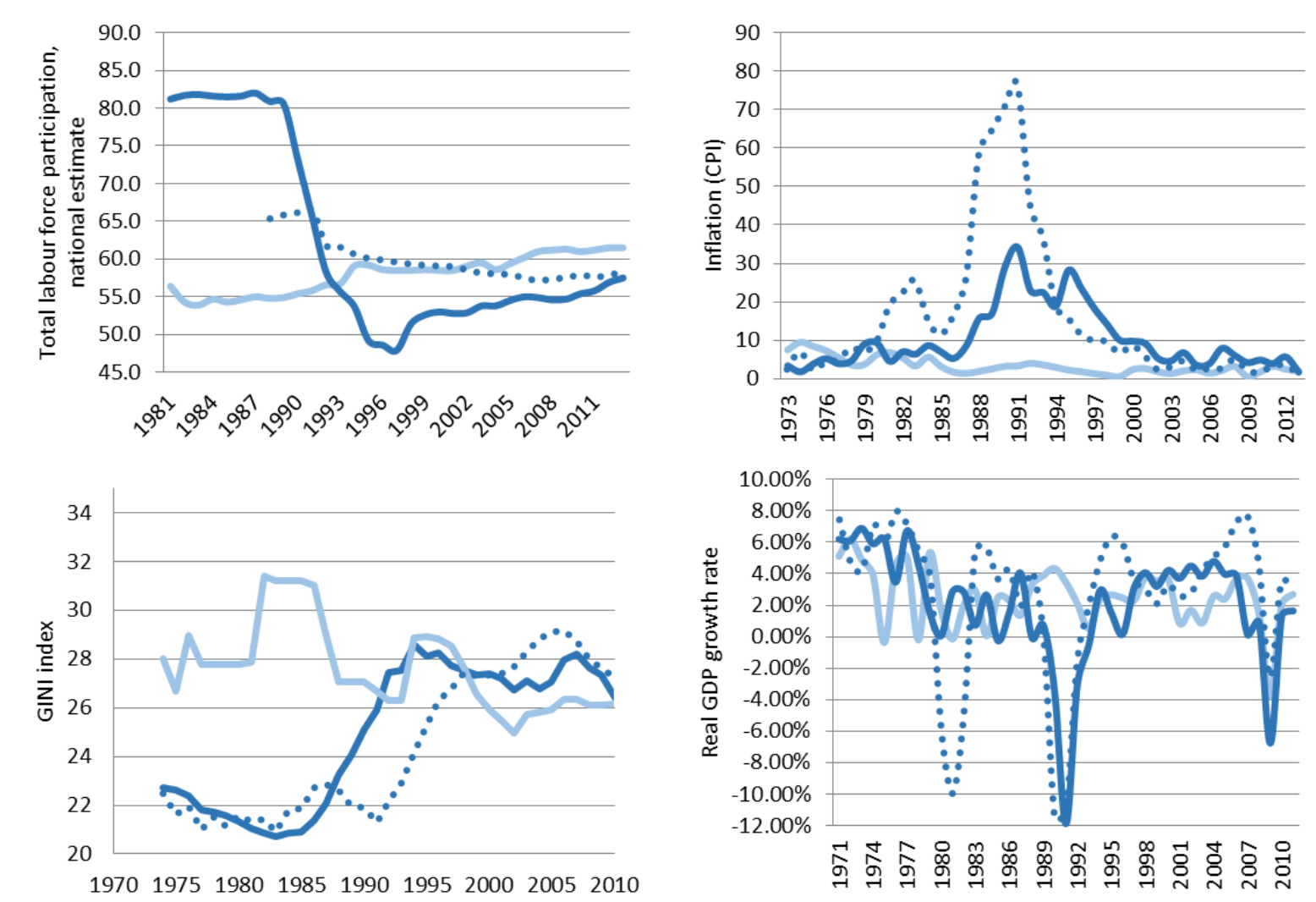

Hungary $\ldots .$. Visegrád average

Austria

source: GDP: Penn World Table; Inflation, Total labour force participation rate: World Development Indicators; GINI (five year moving average), based on UNU WIDER World Income Inequality Database, in cases, where multiple GINI coefficients were reported citing different sources, the average value was calculated. 
The Wounds of Post-Socialism

Table A1. Review of within country studies on the social determinants of mortality in Hungary

\begin{tabular}{|c|c|c|c|c|c|c|c|c|}
\hline Reference & Year & $\begin{array}{l}\text { Citations in } \\
\text { Scopus }\end{array}$ & $\begin{array}{l}\text { Level } \\
\text { analysis }\end{array}$ & of & $\begin{array}{l}\text { Time } \\
\text { scope }\end{array}$ & $\begin{array}{l}\text { Study } \\
\text { design }\end{array}$ & Method & $\begin{array}{l}\text { Dependent } \\
\text { variable }\end{array}$ \\
\hline $\begin{array}{l}\text { Compton } \\
\text { (1985) }\end{array}$ & 1985 & 15 & National & & $\begin{array}{l}1960- \\
1980\end{array}$ & $\begin{array}{l}\text { Time } \\
\text { series }\end{array}$ & $\begin{array}{l}\text { Description } \\
\text { of trends }\end{array}$ & $\begin{array}{l}\text { Morality by } \\
\text { gender, age and } \\
\text { causes of death }\end{array}$ \\
\hline $\begin{array}{l}\text { Orosz } \\
\text { (1990a) }\end{array}$ & 1990 & 14 & National & & $\begin{array}{l}1930- \\
1985\end{array}$ & $\begin{array}{l}\text { Time } \\
\text { series }\end{array}$ & $\begin{array}{l}\text { Description } \\
\text { of trends }\end{array}$ & $\begin{array}{l}\text { Mortality by } \\
\text { gender; cause- } \\
\text { specific } \\
\text { mortality rates }\end{array}$ \\
\hline $\begin{array}{l}\text { Orosz } \\
\text { (1990b) }\end{array}$ & 1990 & 0 & National & & $\begin{array}{l}1930- \\
1985\end{array}$ & $\begin{array}{l}\text { Time } \\
\text { series }\end{array}$ & $\begin{array}{l}\text { Description } \\
\text { of trends }\end{array}$ & $\begin{array}{l}\text { Mortality by } \\
\text { gender; cause- } \\
\text { specific } \\
\text { mortality rates }\end{array}$ \\
\hline $\begin{array}{l}\text { Molnár } \\
\text { (1992) }\end{array}$ & 1992 & 1 & National & & $\begin{array}{l}1930- \\
1979\end{array}$ & $\begin{array}{l}\text { Time } \\
\text { series }\end{array}$ & $\begin{array}{l}\text { Description } \\
\text { of trends }\end{array}$ & $\begin{array}{l}\text { Mortality by } \\
\text { causes of death, } \\
\text { occupation, } \\
\text { marital status }\end{array}$ \\
\hline
\end{tabular}

Male mortality for men aged between 35-59 increased by at least 50 per cent; 90 per cent in the case of the age group 45-49 between 1966 and 1980. Steepest increase in deaths due to cancer, cardio- and cerebrovascular diseases, liver diseases, accidents and suicides.

Analysis of occupational, educational, urban/rural and regional data over several decades demonstrate large disparities in the availability of health care and in infan and adult mortality. Mortality has been particularly high for middle-aged males.

The trend in the life expectancy of the Hungarian population deviates away from that in advanced Western countries and is accompanied by increasing social and regional differences in mortality. This phenomenon can be interpreted as a 'social cost' of post-1945 socio-economic development.

Mortality increased most significantly among cooperative peasants, decreased among intellectuals, and stayed the same among workers between 1963 and 1981. Participation in the secondary economy lead to an increase in the 


\begin{tabular}{|c|c|c|c|c|c|c|c|}
\hline $\begin{array}{l}\text { Makara } \\
(1994)\end{array}$ & 1994 & 15 & National & $\begin{array}{l}1960- \\
1990\end{array}$ & $\begin{array}{l}\text { Time } \\
\text { series }\end{array}$ & $\begin{array}{l}\text { Description } \\
\text { of trends }\end{array}$ & $\begin{array}{l}\text { All-cause } \\
\text { mortality }\end{array}$ \\
\hline $\begin{array}{l}\text { Hajdu, } \\
\text { McKee, and } \\
\text { Bojan (1995) }\end{array}$ & 1995 & 53 & National & $\begin{array}{l}1969- \\
1991\end{array}$ & $\begin{array}{l}\text { Time } \\
\text { series }\end{array}$ & $\begin{array}{l}\text { Description } \\
\text { of trends }\end{array}$ & $\begin{array}{l}\text { Mortality by } \\
\text { marital status }\end{array}$ \\
\hline $\begin{array}{l}\text { Klinger } \\
(2003)\end{array}$ & 2003 & - & Subregion & $\begin{array}{l}1996- \\
2000\end{array}$ & $\begin{array}{l}\text { Time } \\
\text { series }\end{array}$ & $\begin{array}{l}\text { Description } \\
\text { of trends }\end{array}$ & $\begin{array}{l}\text { All-cause } \\
\text { mortality }\end{array}$ \\
\hline
\end{tabular}

Skrabski,

Kopp, and

Kawachi

$2003 \quad 84$

County

1995

(2003)

Kopp et al.

(2004)

$200472 \quad$ County

Correlation,

linear

regression

$(\mathrm{N}=12640)$

Correlation,

linear

Cross

sectional regression

$(\mathrm{N}=12,643)$

workload, stress, status-inconsistency and mortality.

Mortality trends in Western and Eastern Europe have differed considerably during the past three decades. No political strategies were initiated or launched to combat the mortality and morbidity tendencies.

Increases in premature mortality in Hungary have been greatest among men who are widowed, have never married and, in particular, are divorced, with married men appearing to have been relatively protected.

Morality is highest in the north-eastern and in the southwestern sub-regions of the country and lowest in the northwestern sub-regions and Budapest. Mortality is the highest in the sub-regions with the lowest economic development indicators.

Distrust, Reciprocity, Received help from civil associations, Age,

Gender specific mortality rates

Unemployment rate, Education, Income (GDP), Spirit consumption, Smoking

Self-rated health, self-rated working Gender specific disability, subjective social status, mortality rates objective social status (income,

education)
GDP, unemployment and education are the most important determinants of mortality, but all of the social capital variables were also significantly associated with middle age mortality. Help from civic organisations among men, and perceptions of reciprocity among women were particularly important.

Among men self-rated health explained 67.3 per cent of mortality (objective measures of social status not included), while subjective social status 6.7 per cent. Among women, subjective social status is more important (18.8\%). 
Skrabski,

Kopp, and

Kawachi

$2004 \quad 50$

Subregion

2002

(2004)

\section{Kopp,}

Csoboth, and

Réthelyi

$2004 \quad 12$

County

1988

1995

$\begin{array}{lll}\text { Cross } & \text { Linear } & \text { Mortality } \\ \text { sectional } & \text { regression } & \text { gender }\end{array}$

by gender

GDP, average personal income, income inequality, depression

Correlation,

Cross linear

sectional regression

(2005)

$200521 \quad$ Subregion

2002

$$
(\mathrm{N}=12,643)
$$

\section{Kopp et al.}

(2006)

$200629 \quad$ Subregion

2002

Cross

Correlation,

linear

regression

$(\mathrm{N}=12,643)$

Gender specific

mortality,

ischaemic heart

disease, and

cerebrovascular

mortality rates

Cox

proportional

Years of education, Collective

efficacy, Perceived reciprocity,

Social mistrust, Competitive

attitude, Membership in civic

organisation, Religious

involvement, Cigarettes per day,

Spirit consumption, Taxable

income

Male standardised mortality rates were highly significantly connected with depressive symptomatology, while female mortality rates and depressive symptomatology were not significantly connected, as well as measures of income and economic performance.

Education and subjective social status of women were more significantly associated with middle aged male mortality, than were male education, male subjective social status, and income

Control at work, Social support at work, Job security, Week day work hours, Weekend work hours,

The authors find that low socioeconomic status, exerts its Personal income, Education, Social income and low job security, low social support from costatus, Unemployment rate, workers and friends, low control at work, anomie, and Depression, Hostility, Anomie, hostility. Social support, Smoking, Drinking

Kopp et al. $2007 \quad 40$

Individual

2002; Survival
Self-rated health, social status,

Mortality
The health consequences of low education among men health, ontological might be mostly explained by chronic stress caused by 
The Wounds of Post-Socialism

(2007)

Kovács

(2008)

$2008 \quad 7$

National

1986- Time

2005 series

1990

2000 ;

2007

(2008)

$2008-$

County

Almasi et al.

(2009)

$2009 \quad 26$

Individual

2002;

2004

Survival

analysis

Uzzoli and
Szilágyi
(2009)

County

1970- Time

2007 series
Description

of trends

Conditional

logistic

regression

$(\mathrm{N}=194+$

Suicide

194

control).

gender

odel

$(\mathrm{N}=12600)$

Age

standardised

gender specific

suicide, alcohol

related mortality

rates

All-cause

mortality, life

expectancy by

gender

Marital status, Ethnic origin,

Relationship status, Child, Social engagement, Religion, Education, Standard of living, Unemployment, Concerns over work prospects, Suicide of relative, Childhood life events, Mental illness, Smoking

All-cause

Description mortality, life

of trends expectancy by

gender social-support, health behaviour. insecurity, work-related stress, work- and close-partner-related factors, and the toxic

components of this interaction are depression, hopelessness, and anxiety.

The authors found falling suicide rates in all sociodemographic groups, except well-educated middle aged men. Suicide has fallen more among women than men, more among the elderly than the young and more among the more educated than the less educated.

There are significant mortality differentials between the Western and the Eastern half of the country. The difference between the average life expectancy of the counties of the best and the worst values is 2.5 years.

Being unmarried or having no current relationship, lack of other social contacts, low educational attainment, history of self-harm, current diagnosis of affective disorder, unemployment, concern over work prospects, changes in living standards were also associated with suicide.

Male life expectancy peaked in 1966 and then started to decline constantly. An improvement was observable between 1984 and 1987. Life expectancy declined again between 1988 and 1994, and started to improve afterwards. Life expectancy surpassed the level of 1966 in 2001. 
The Wounds of Post-Socialism

Juhász et al.

(2010)

$2010 \quad 11 \quad$ Municipality

1998; Survival

2004 analysis

Hierarchical

Bayesian

Method

Mortality due to

diseases of the

circulatory

system

1985- Time

2008 series

Regression Suicide

(2011)

National

Cox

Kopp et al.

(2011)

20118

Individual

2002; Survival

2005 analysis

proportional

hazard

model

(N=12668)

\section{Uzzoli}

(2011)

2011 -

County

2009

Cross

sectional

Correlation

Life expectancy GDP, employment

by gender

unemployment rate income, and car ownership)

Mortality gender status.
Deprivation index (composed of Areas of significantly high deprivation were identified in

qualification,

unemployment, one-parent families,

large families, density of housing

National averages of tobacco use, antidepressant use, alcohol consumption, total number of manhours worked per year by psychiatrists, real GDP growth

Education, occupational class, income, subjective social status, control available at the workplace,

job security, social support from

colleagues, depression, selfefficacy, smoking, alcohol, marital

Life expectancy in Hungary has been increasing recently but in a geographically uneven distribution. In the connection between average life expectancy at birth and economic development, GDP per capita, average income, and unemployment rate are equally determinative.

Alcohol consumption, tobacco Following the system change, up until 1993 the extensive consumption, extra work in the hidden economy, together with rapidly growing second economy (proxied with unemployment played a major role in the deterioration of inflation), GDP, number of doctors, health among men mostly through adverse lifestyle 
Nagy et al.

Nagy et al.

Rihmer et al.

Balint et al

20147

Subregion

2005

2011

\section{Cross}

sectional

2000- Time

Fountoulakis

$2014 \quad 4$
National
Regression

Age and gender standardised

suicide

mortality ratio

unemployment

$\begin{array}{ll}\text { Hierarchical } & \text { Mortality } \\ \text { Bayesian } & \text { amenable to Socioeconomic status } \\ \text { method } & \text { health care }\end{array}$

Deprivation index (composed of income, qualification, unemployment, one-parent families, large families, density of housing and car ownership)

Suicide by
gender, marital status and age

religious and political integration, travel time accessibility of psychiatric services, alcohol consumption, unemployment and disability pension

Correlation Suicide rates changes

Mortality amenable to health care has been declining in Hungary since the 1980s, but was still 2-3 times higher than the EU average in 2004. A statistically significant association was found between amenable mortality and deprivation status.

A statistically significant association was found between mortality and deprivation status in males. Areas of highest age-adjusted relative risks were found, for males, in the south-western part, and at the eastern border of the country.

During the time period from 1985 to 2008, only antidepressant prescription and tobacco consumption showed significant associations (a negative and a positive, respectively) with suicide mortality in Hungary while alcohol consumption and changes in GDP did not.

Mortality was significantly associated with the "political integration" variable in a negative and with "lack of religious integration" and "disability pension" variables in a positive manner. Associations were not significant for the remaining explanatory variables

The correlation of unemployment with suicidality gave a peak strong positive correlation at 5 years for the general population. Unemployment might be associated with suicidality in the general population only after $3-5$ years. 
The Wounds of Post-Socialism

\begin{tabular}{|c|c|c|c|c|c|c|c|}
\hline $\begin{array}{l}\text { Kovács } \\
(2014)\end{array}$ & 2014 & - & National & $\begin{array}{l}1971- \\
2008\end{array}$ & $\begin{array}{l}\text { Time } \\
\text { series }\end{array}$ & $\begin{array}{l}\text { Description } \\
\text { of trends }\end{array}$ & $\begin{array}{l}\text { Cause specific } \\
\text { mortality by } \\
\text { education }\end{array}$ \\
\hline
\end{tabular}

Inequalities in mortality grew in almost every category by causes of death, mainly due to a steeper decline in mortality among the more educated. Nutrition-related and cardiovascular diseases are largely responsible for the onset of mortality inequalities since 1980 . 


\section{The Wounds of Post-Socialism}

Table 1. The performance of different variable groups across the studies

\begin{abstract}
Variables
Socioeconomic status (education, income, standard of living,

occupational class, household income, car ownership, personal computer ownership, deprivation index [composed of income, qualification, unemployment, one-parent families, large families, density of housing and car ownership])

Mental health (Depression, Hopelessness, Hostility, Suicide of relative, Mental illness, depressive symptoms, Not been out socially, self-efficacy, low cheerfulness, Hospital Anxiety Score)
\end{abstract}

Smoking (Cigarettes per day, National averages of tobacco use)

Alcohol (Spirit consumption, drinking)

Social capital (Distrust, Reciprocity, Received help from civil associations, Collective efficacy, Perceived reciprocity, Social mistrust, Competitive attitude, Membership in civic organisation, Social support from friends, parents, partner,
Significant

Kopp et al. (2007); Skrabski, Kopp, and Kawachi (2003); Kopp et al. (2004); Skrabski, Kopp, and Kawachi (2004); Kopp et al. (2005); Kopp et al. (2006); Almasi et al. (2009); Juhász et al. (2010); Kopp et al. (2011); Nagy et al. (2012); Nagy et al. (2013)

Kopp et al. (2007), Kopp, Csoboth, and Réthelyi (2004); Kopp et al. (2006); Almasi et al. (2009); Döme et al. (2011); Kopp et al. (2011)

Lackó (2011); Skrabski, Kopp, and Kawachi (2004) Kopp et al. (2006); Almasi et al. (2009); Döme et al. (2011); Kopp et al. (2011)

Lackó (2011); Skrabski, Kopp, and Kawachi (2003); Skrabski, Kopp, and Kawachi (2004); Kopp et al. Döme et al. (2011); 5 (2006); Almasi et al. (2009)

Kopp et al. (2007); Skrabski, Kopp, and Kawachi (2003); Skrabski, Kopp, and Kawachi (2004); Kopp et al. (2006); Kopp et al. (2011)
Döme et al. (2011)
Balint et al. (2014)

Insignificant

Sig\#

Insig\#

Réthelyi (2004)

Skrabski, Kopp,

and Kawachi

(2003); Kopp et al.

2

$75 \%$

(2007) 
civic organisations, social support from colleagues ,Social engagement)

Social integration (religious involvement, Religion, political participation, anomie)

Stress (Control at work, control available at the workplace, dissatisfaction with the job, Job security, Week day work hours, Weekend work hours, Concerns over work prospects,

Overwork in the second economy proxied with inflation)

Subjective social status

Economic performance (GDP, real GDP growth, Aggregate income)

\section{Unemployment (Unemployment rate, employment)}

Family status (Relationship status, Living alone, Child)

Income inequality (SD of personal income)

Medical services (travel time accessibility of psychiatric services, total number of man-hours worked per year by psychiatrists, antidepressant use, relative number of doctors)
Kopp et al. (2007); Skrabski, Kopp, and Kawachi (2004); Kopp et al. (2006); Balint et al. (2014); Almasi et al. (2009)

Kopp et al. (2007); Lackó (2011); Kopp et al. (2006);

Döme et al. (2011); Kopp et al. (2011)

Kopp et al. (2004); Kopp et al. (2005); Kopp et al. (2006); Kopp et al. (2011)

Kopp, Csoboth, and Réthelyi (2004); Lackó (2011); Skrabski, Kopp, and Kawachi (2003)

Döme et al. (2011)

Skrabski, Kopp, and Kawachi (2003); Kopp et al. (2006); Lackó (2011)

Balint et al. (2014)

Almasi et al. (2009); Kopp et al. (2011)

Kopp, Csoboth, and Réthelyi (2004)
$50.0 \%$

$100.0 \%$

$00 \%$

$100.0 \%$

$0.0 \%$
Lackó (2011); 0
Balint et al. (2014) 


\section{References}

Almasi, Kitty, Nora Belso, Navneet Kapur, Roger Webb, Jayne Cooper, Sarah Hadley, Michael Kerfoot, et al. 2009. "Risk factors for suicide in Hungary: a case-control study." $B M C$ Psychiatry 9 (1):45.

Arinaminpathy, Nimalan, and Christopher Dye. 2010. "Health in financial crises: economic recession and tuberculosis in Central and Eastern Europe." Journal of the Royal Society Interface 7 (52):1559-69.

Azarova, Aytalina, Darja Irdam, Alexi Gugushvili, Mihaly Fazekas, Gábor Scheiring, Pia Horvat, Denes Stefler, et al. 2017. "The effect of rapid privatisation on mortality in mono-industrial towns in post-Soviet Russia: a retrospective cohort study." The Lancet Public Health 2017 (11 April):1-8.

Balint, Lajos, Peter Dome, Gergely Daroczi, Xenia Gonda, and Zoltan Rihmer. 2014. "Investigation of the marked and long-standing spatial inhomogeneity of the Hungarian suicide rate: A spatial regression approach." Journal of Affective Disorders 155 (0):180-5.

Barlow, P., A. Reeves, M. McKee, and D. Stuckler. 2015. "Austerity, precariousness, and the health status of Greek labour market participants: Retrospective cohort analysis of employed and unemployed persons in 2008-2009 and 2010-2011." J Public Health Policy 36 (4):452-68.

Bhattacharya, Jay, Christina Gathmann, and Grant Miller. 2013. "The Gorbachev Anti-Alcohol Campaign and Russia's Mortality Crisis." American Economic Journal: Applied Economics 5 (2):232-60.

Bobak, Martin, and Richard G. A. Feachem. 1995. "Air pollution and mortality in Central and Eastern Europe." The European Journal of Public Health 5 (2):82-6.

Bobak, Martin, and Michael Marmot. 1996. "East-West mortality divide and its potential explanations: proposed research agenda." BMJ : British Medical Journal 312 (7028):421-5.

Bohle, Dorothee, and Béla Greskovits. 2007. "Neoliberalism, Embedded Neoliberalism, and Neocorporatism: Towards Transnational Capitalism in Central-Eastern Europe." West European Politics 30 (3):443-66.

Boycko, Maxim, Andrei Shleifer, Robert W. Vishny, Stanley Fischer, and Jeffrey D. Sachs. 1993. "Privatizing Russia." Brookings Papers on Economic Activity 1993 (2):139-92.

Böröcz, József. 1999. "From comprador state to auctioneer state: property change, realignment, and peripheralization in post-state-socialist Central and Eastern Europe." In States and Sovereignity in the Global Economy, edited by David A. Smith, Dorothy J. Solinger and Steven C. Topik, 193-209. London \& New York: Routledge.

Brainerd, Elizabeth. 1998. "Market reform and mortality in transition economies." World Development 26 (11):2013-27. 
The Wounds of Post-Socialism

Brainerd, Elizabeth, and David M. Cutler. 2005. "Autopsy on an Empire: Understanding Mortality in Russia and the Former Soviet Union." The Journal of Economic Perspectives 19 (1):107-30.

Bunce, Valerie. 2006. "Global patterns and postcommunist dynamics." Orbis 50 (4):601-20.

Burawoy, Michael, and Katherine Verdery. 1999. Uncertain Transition: Ethnographies of Change in the Postsocialist World. Lanham: Rowman \& Littlefield.

Centre for Reviews and Dissemination. 2008. Systematic Reviews: CRD's guidance for undertaking reviews in health care. York: University of York.

Chen, Lincoln C., Friederike Wittgenstein, and Elizabeth McKeon. 1996. "The Upsurge of Mortality in Russia: Causes and Policy Implications." Population and Development Review 22 (3):51730.

Clair, Amy, Rachel Loopstra, Aaron Reeves, Martin McKee, Danny Dorling, and David Stuckler. 2016. "The impact of housing payment problems on health status during economic recession: A comparative analysis of longitudinal EU SILC data of 27 European states, 2008-2010." SSMPopulation Health 2:306-16.

Coburn, David. 2000. "Income inequality, social cohesion and the health status of populations: the role of neo-liberalism." Social Science \& Medicine 51 (1):135-46.

Cockerham, William C. 1997. "The Social Determinants of the Decline of Life Expectancy in Russia and Eastern Europe: A Lifestyle Explanation." Journal of Health and Social Behavior 38 (2):117-30.

Cockerham, William C., Brian P. Hinote, Geoffrey B. Cockerham, and Pamela Abbott. 2006. "Health lifestyles and political ideology in Belarus, Russia, and Ukraine." Social Science \& Medicine 62 (7):1799-809.

Cockerham, William C., M. Christine Snead, and Derek F. DeWaal. 2002. "Health Lifestyles in Russia and the Socialist Heritage." Journal of Health and Social Behavior 43 (1):42-55.

Compton, P. A. 1985. "Rising Mortality in Hungary." Population Studies 39 (1):71-86.

Cornia, Giovanni A., and Renato Paniccià. 2000. "The Transition Mortality Crisis: Evidence, Interpretation and Policy Responses." In The mortality crisis in transitional economies, edited by Giovanni A. Cornia and Renato Paniccià, 3-37. Oxford: Oxford University Press.

Cornia, Giovanni Andrea, and Renato Paniccià. 1996. "The transition's population crisis: An econometric investigation of nuptiality, fertility and mortality in severely distressed economies." MOST: Economic Policy in Transitional Economies 6 (1):95-129.

De Vogli, Roberto. 2011. "Neoliberal globalisation and health in a time of economic crisis." Social Theory \& Health 9 (4):311-25.

Döme, Pál, Balázs Kapitány, Györgyi Ignits, Lajos Porkoláb, and Zoltáín Rihmer. 2011. "Tobacco consumption and antidepressant use are associated with the rate of completed suicide in Hungary: An ecological study." Journal of Psychiatric Research 45 (4):488-94. 
Earle, John S., and Scott Gehlbach. 2010. "Mass Privatisation and the Post-Communist Mortality Crisis: Is There Really a Relationship?". Kalamazoo, MI: W.E. Upjohn Institute for Employment Research, Upjohn Institute Working Paper No. 10-162.

Eberstadt, Nicholas. 2010. "The Enigma of Russian Mortality." Current History 109 (729):288.

Elekes, Zsuzsanna, and Borbála Paksi. 1999. "Are Politics Getting People Down? Changing Trends in Suicide and Alcoholism." In Hungary in Flux, edited by Zsolt Spéder, 135-48. Hamburg: Krämer.

EUROSTAT. 2015. "Employment (main characteristics and rates) - annual averages ". Eurostat Online Database. URL = http://appsso.eurostat.ec.europa.eu/nui/show.do?dataset=lfsi_emp_a\&lang=en (last access: 13 November 2016).

Fountoulakis, Konstantinos, Xenia Gonda, Peter Dome, Pavlos Theodorakis, and Zoltan Rihmer. 2014. "Possible delayed effect of unemployment on suicidal rates: the case of Hungary." Annals of General Psychiatry 13 (1):12.

Frankel, Jeffrey A., and George Saravelos. 2012. "Can leading indicators assess country vulnerability? Evidence from the 2008-09 global financial crisis." Journal of International Economics 87 (2):216-31.

Gaal, Peter, Szabolcs Szigeti, Marton Csere, Matthew Gaskins, and Dimitra Panteli. 2011. "Hungary Health System Review." Health systems in transition 13 (5):1-266.

Gentile, Michael. 2012. "Mass Privatisation, Unemployment and Mortality." Europe-Asia Studies 64 (4):785-7.

Ginter, Emil. 1995. "High cardiovascular mortality in postcommunist countries: participation of oxidative stress?" International Journal for Vitamin and Nutrition Research 66 (3):183-9.

Hajdu, P., M. McKee, and F. Bojan. 1995. "Changes in Premature Mortality differentials by marital status in Hungary and in England and Wales." The European Journal of Public Health 5 (4):259-64.

Haynes, Mike. 2013. "Social Inequality and the Continuing Russian Mortality Crisis." Debatte: Journal of Contemporary Central and Eastern Europe 21 (1):25-49.

Higgins, Julian PT, and Sally Green. 2011. Cochrane Handbook for Systematic Reviews of Interventions. Version 5.1.0 [updated March 2011]. The Cochrane Collaboration: Available at www.handbook.cochrane.org.

Irdam, Darja, Gabor Scheiring, and Lawrence King. 2015. "Mass Privatization." In Palgrave Dictionary of Emerging Markets and Transition Economics, edited by Jens Hölscher and Horst Tomann, 488-507. Houndmills, Basingstoke: Palgrave Macmillan.

Józan, Péter. 1996. "Changes in Mortality in Hungary between 1980 and 1994." In Demography of contemporary Hungarian society (Atlantic Studies on Society in Change, vol. 85), edited by Pál Péter Tóth and Emil Valkovics, 111-38. Highland Lakes, New Jersey: Atlantic Research and Publications. 
- 2002. "The Trend of the Mortality in the XX. Century and the Mortality at the Turn of the Millennium [in Hungarian]." Magyar Tudomány 2002 (4-5):419-40.

Juhász, Attila, Csilla Nagy, Anna Páldy, and Linda Beale. 2010. "Development of a Deprivation Index and its relation to premature mortality due to diseases of the circulatory system in Hungary, 1998-2004." Social Science \& Medicine 70 (9):1342-9.

Kalb, Don. 2015. "'Theory from the East': visions of Labor from the rubble of 'democratic transition' in Central and Eastern Europe." Baltic Worlds 2015 (3-4):17-29.

Kaminsky, Graciela L., Saul Lizondo, and Carmen M. Reinhart. 1998. "Leading Indicators of Currency Crises." IMF Staff Papers 45 (1):1-48.

Karanikolos, Marina, Philipa Mladovsky, Jonathan Cylus, Sarah Thomson, Sanjay Basu, David Stuckler, Johan P. Mackenbach, and Martin McKee. 2013. "Financial crisis, austerity, and health in Europe." The Lancet 381 (9874):1323-31.

Katikireddi, Srinivasa Vittal, Martin Higgins, Katherine Elizabeth Smith, and Gareth Williams. 2013. "Health inequalities: the need to move beyond bad behaviours." Journal of Epidemiology and Community Health 67 (9):715.

Kentikelenis, Alexander E. 2017. "Structural adjustment and health: A conceptual framework and evidence on pathways." Social Science \& Medicine 2017 (Online first):1-17.

King, Lawrence, and Balázs Váradi. 2002. "Beyond Manichean economics: foreign direct investment and growth in the transition from socialism." Communist and Post-Communist Studies 35 (1):121.

Klinger, András. 2003. "Mortality differences between the subregions of Hungary." Demográfia 48 (5):21-53.

Kopp, Mária, Csilla T. Csoboth, and János Réthelyi. 2004. "Psychosocial Determinants of Premature Health Deterioration in a Changing Society: The Case of Hungary." Journal of Health Psychology 9 (1):99-109.

Kopp, Mária, and János Réthelyi. 2004. "Where psychology meets physiology: chronic stress and premature mortality - the Central-Eastern European health paradox." Brain Research Bulletin $62(5): 351-67$.

Kopp, Mária, Árpád Skrabski, Ichiro Kawachi, and Nancy E. Adler. 2005. "Low socioeconomic status of the opposite sex is a risk factor for middle aged mortality." Journal of Epidemiology and Community Health 59 (8):675-8.

Kopp, Mária, Árpád Skrabski, Krisztina D. László, and Imre Janszky. 2011. "Gender Patterns of Socioeconomic Differences in Premature Mortality: Follow-up of the Hungarian Epidemiological Panel." International Journal of Health Behavior 18 (1):22-34.

Kopp, Mária, Árpád Skrabski, János Réthelyi, Ichiro Kawachi, and Nancy E. Adler. 2004. "Self-Rated Health, Subjective Social Status, and Middle-Aged Mortality in a Changing Society." Behavioral Medicine 30 (2):65-72. 
Kopp, Mária, Árpád Skrabski, Zsuzsa Szántó, and Johannes Siegrist. 2006. "Psychosocial determinants of premature cardiovascular mortality differences within Hungary." Journal of Epidemiology and Community Health 60 (9):782-8.

Kopp, Mária, Árpád Skrabski, and Sándor Szedmák. 2000. "Psychosocial risk factors, inequality and self-rated morbidity in a changing society." Social Science \& Medicine 51 (9):1351-61.

Kopp, Mária, Árpád Skrabski, Sándor Székely, Adrienne Stauder, and Redford Williams. 2007. "Chronic Stress and Social Changes: Socioeconomic Determination of Chronic Stress." Annals of the New York Academy of Sciences 1113 (1):325-38.

Korotayev, Andrey. 2008. "The Russian demographic crisis in cross-national perspective." In Russia and Globalization: Identity, Security, and Society in an Era of Change, edited by Douglas W. Blum, 37-78. Baltimore, MD: Johns Hopkins University Press.

Kovács, Katalin. 2008. "Suicide and alcohol-related mortality in Hungary in the last two decades." International Journal of Public Health 53 (5):252-9.

. 2014. "Social Disparities in the Evolution of an Epidemiological Profile: Transition Processes in Mortality Between 1971 and 2008 in an Industrialized Middle Income Country: The Case of Hungary." In Mortality in an International Perspective, edited by Jon Anson and Marc Luy, 79117. Cham: Springer International Publishing.

Kubrin, Charis E., Tim Wadsworth, and Stephanie DiPietro. 2006. "Deindustrialization, Disadvantage and Suicide among Young Black Males." Social Forces 84 (3):1559-79.

Lackó, Mária. 2011. "The Poor Health Status of the Hungarians; Comparative Macro-Analysis of the Likely Explanatory Factors on Hungarian and Austrian Data, 1960-2004." DANUBE: Law and Economics Review 2011 (3):1-21.

. 2015. "Some explanation of disparities of mortality rates of working age population in Eastern, Central and Western Europe". Discussion Papers 2015/35, Institute of Economics, Centre for Economic and Regional Studies, Hungarian Academy of Sciences, Budapest.

Leinsalu, Mall, Irina Stirbu, Denny Vågerö, Ramuné Kálediené, Katalin Kovács, Bogdan Wojtyniak, Wiktoria Wróblewska, Johan P. Mackenbach, and Anton E. Kunst. 2009. "Educational inequalities in mortality in four Eastern European countries: divergence in trends during the post-communist transition from 1990 to 2000." International journal of epidemiology 38 (2):512-25.

Leon, David A., Laurent Chenet, Vladimir M. Shkolnikov, Sergei Zakharov, Judith Shapiro, Galina Rakhmanova, Sergei Vassin, and Martin McKee. 1997. "Huge variation in Russian mortality rates 1984-94: artefact, alcohol, or what?" The Lancet 350 (9075):383-8.

Lipset, Seymour Martin. 1994. "The social requisites of democracy revisited." American Sociological Review 59 (1):1.

Lipton, David, and Jeffrey D Sachs. 1992. "Prospects for Russia's Economic Reforms." Brookings Papers on Economic Activity 1992 (2):213-83. 
The Wounds of Post-Socialism

Mackenbach, Johan P., Yannan Hu, and Caspar W.N. Looman. 2013. "Democratization and life expectancy in Europe, 1960-2008." Social Science \& Medicine 93 (September 2013):166-75.

Mackenbach, Johan P., Anton E. Kunst, Feikje Groenhof, Jens-Kristian Borgan, Giuseppe Costa, Fabrizio Faggiano, Péter Józan, et al. 1999. "Socioeconomic inequalities in mortality among women and among men: an international study." American Journal of Public Health 89 (12):1800-6.

Mackenzie, Mhairi, Chik Collins, John Connolly, Mick Doyle, and Gerry McCartney. 2016. "Working-class discourses of politics, policy and health: 'I don't smoke; I don't drink. The only thing wrong with me is my health'." Policy \& Politics Online first:1-19.

Makara, Peter. 1994. "Policy implications of differential health status in East and West Europe. The case of Hungary." Social Science \& Medicine 39 (9):1295-302.

Marmot, Michael. 2004. The Status Syndrome: How Social Standing Affects Our Health and Longevity. New York: Owl Book.

Marmot, Michael, and Martin Bobak. 2000. "Psychosocial and Biological Mechanisms behind the Recent Mortality Crisis in Central and Eastern Europe." In The mortality crisis in transitional economies, edited by Giovanni A. Cornia and Renato Paniccia, 127-50. Oxford Oxford University Press.

McKee, Martin. 2001. "The health consequences of the collapse of the Soviet Union." In Poverty, inequality and health: an international perspective. New York: Oxford UP, edited by D.A. Leon and G. Walt, 138-45. Oxford: Oxford University Press.

McKee, Martin, and Annie Britton. 1998. "The Positive Relationship between Alcohol and Heart Disease in Eastern Europe: Potential Physiological Mechanisms." Journal of the Royal Society of Medicine 91 (8):402-7.

McKee, Martin, and Vladimir M. Shkolnikov. 2001. "Understanding the toll of premature death among men in eastern Europe." British Medical Journal 323 (7320):1051-5.

McLean, Katherine. 2016. "There's nothing here": Deindustrialization as risk environment for overdose." International Journal of Drug Policy 29:19-26.

Minagawa, Yuka. 2013. "The Social Consequences of Postcommunist Structural Change: An Analysis of Suicide Trends in Eastern Europe." Social Forces 91 (3):1035-56.

Molnár, László. 1992. "Social causes of high morbidity and mortality rates in Hungary." International Review of Sociology 3 (2):35-67.

Morava, E., E. Végh, I. Bóna, I. Kiss, B. Oroszi, and P. Józan. 2000. "Health risk factors and mortality in Pecs City, Hungary in the 1990s." Central European journal of public health 8 (2):109-13.

Murrell, Peter. 1992. "Evolutionary and radical approaches to economic reform." Economics of Planning 25 (1):79-95. 
Nagy, Csilla, Attila Juhász, Linda Beale, and Anna Páldy. 2012. "Mortality amenable to health care and its relation to socio-economic status in Hungary, 2004-08." The European Journal of Public Health 22 (5):620-4.

Nagy, Csilla, Attila Juhász, Zoltán Papp, and Linda Beale. 2013. "Hierarchical spatio-temporal mapping of premature mortality due to alcoholic liver disease in Hungary, 2005-2010." The European Journal of Public Health 24 (5):827-33.

Nell, Jacob, and Kitty Stewart. 1994. "Death in Transition: The rise in the death rate in Russia since 1992". Innocenti Occasional Papers, Economic Policy, Series 45, UNICEF ICDC, Florence.

Orosz, Eva. 1990a. "The Hungarian country profile: Inequalities in health and health care in Hungary." Social Science \& Medicine 31 (8):847-57.

—. 1990b. "Regional inequalities in the Hungarian health system." Geoforum 21 (2):245-59.

Petticrew, Mark, and Helen Roberts. 2006. Systematic Reviews in the Social Sciences: A Practical Guide. Oxford: Blackwell.

Piko, Bettina F. 2004. "Interplay between Self and Community: A Role for Health Psychology in Eastern Europe's Public Health." Journal of Health Psychology 9 (1):111-20.

Plasser, Fritz, Peter Ulram, and Harald Waldrauch. 1998. Democratic Consolidation in East-Central Europe. Houndmills, Basingstoke: Palgrave MacMillan.

Pogátsa, Zoltán. 2009. "Hungary: From Star Transition Student to Backsliding Member State." Journal of Contemporary European Research 5 (4):597-613.

Rehm, Jürgen, Urszula Sulkowska, Marta Mańczuk, Paolo Boffetta, John Powles, Svetlana Popova, and Witold Zatoński. 2007. "Alcohol accounts for a high proportion of premature mortality in central and eastern Europe." International journal of epidemiology 36 (2):458-67.

Renner, Craig, and Vicente Navarro. 1989. "Why is Our Population of Uninsured and Underinsured Persons Growing? The Consequences of the "Deindustrialization" of the United States." International Journal of Health Services 19 (3):433-42.

Rihmer, Zoltan, Xenia Gonda, Balazs Kapitany, and Peter Dome. 2013. "Suicide in Hungaryepidemiological and clinical perspectives." Annals of General Psychiatry 12 (1):21.

Rind, Esther, Andy Jones, and Humphrey Southall. 2014. "How is post-industrial decline associated with the geography of physical activity? Evidence from the Health Survey for England." Social Science \& Medicine 104:88-97.

Rosefielde, Steven. 2001. "Premature Deaths: Russia's Radical Economic Transition in Soviet Perspective." Europe-Asia Studies 53 (8):1159-76.

Scheiring, Gábor, Darja Irdam, and Lawrence P. King. 2017. "Social Determinants of the PostCommunist Mortality Crisis: A Systematic Review of the Cross-Country Evidence". Manuscript, Department Of Sociology, University of Cambridge.

Sen, Amartya. 1998. "Mortality as an Indicator of Economic Success and Failure." Economic Journal 108 (446):1-25. 
Shkolnikov, Vladimir, and Giovanni A. Cornia. 2000. "The Population Crisis and Rising Mortality in Russia." In The Mortality Crisis in Transition Economies, edited by Andrea Cornia and Renato Panicciá. Oxford: Oxford University Press.

Skrabski, Árpád, Mária Kopp, and Ichiro Kawachi. 2003. "Social capital in a changing society: cross sectional associations with middle aged female and male mortality rates." Journal of Epidemiology and Community Health 57 (2):114-9.

. 2004. "Social capital and collective efficacy in Hungary: cross sectional associations with middle aged female and male mortality rates." Journal of Epidemiology and Community Health 58 (4):340-5.

Smith, Katherine. 2013. "Institutional filters: the translation and re-circulation of ideas about health inequalities within policy." Policy \& Politics 41 (1):81-100.

Stark, David, and László Bruszt. 1998. Postsocialist Pathways: Transforming Politics and Property in East Central Europe. Cambridge: Cambridge University Press.

Stefler, Denes, and Martin Bobak. 2015. "Does the consumption of fruits and vegetables differ between Eastern and Western European populations? Systematic review of cross-national studies." Archives of Public Health 73 (1):29.

Stiglitz, Joseph E. 1999. "Whither Reform? Ten Years of the Transition ". Keynote Address, Annual Bank Conference on Development Economics, Washington, D.C., April 28-30, 1999.

Stuckler, David, Sanjay Basu, and Martin McKee. 2010. "Budget crises, health, and social welfare programmes." BMJ: British Medical Journal 340 (7763):77-9.

Stuckler, David, Lawrence King, and Sanjay Basu. 2008. "International Monetary Fund Programs and Tuberculosis Outcomes in Post-Communist Countries." PloS Medicine 5 (7):1079-90.

Stuckler, David, Lawrence King, and Martin McKee. 2009. "Mass privatisation and the postcommunist mortality crisis: a cross-national analysis." The Lancet 373 (9661):399-407.

Szilágyi, Dániel, and Annamária Uzzoli. 2014. "Spatiality of health inequalities regarding economic crisis in Hungary". Paper prepared for the European Population Conference, 26 - 28 June 2014, Budapest.

Uzzoli, Annamária. 2008. "The mortality situation and its spatial dimension in Hungary." Regionální studia 2008 (2):41-50.

—. 2011. "The Role of Unemployment in the Run of Life Chances in Hungary." International Journal of Population Research 2011:1-9.

Uzzoli, Annamária, and Dániel Szilágyi. 2009. "Life expectancy and its regional inequalities in Hungary." Geographica Pannonica 13 (4):127-36.

Walberg, Peder, Martin McKee, Vladimir Shkolnikov, Laurent Chenet, and David Leon. 1998. "Economic change, crime, and mortality crisis in Russia: regional analysis." BMJ 317 (7154):312-8 . 
The Wounds of Post-Socialism

Walsh, David, Martin Taulbut, and Phil Hanlon. 2009. "The aftershock of deindustrialization — trends in mortality in Scotland and other parts of post-industrial Europe." The European Journal of Public Health:1-7.

Waters, Sarah. 2014. "A Capitalism That Kills: Workplace Suicides at France Télécom." French Politics, Culture \& Society 32 (3):121-41.

WHO. 2010. A conceptual framework for action on the social determinants of health: Social Determinants of Health Discussion Paper 2 (Policy and Practice). Geneva: World Health Organization. 